\title{
An emerging role for prdm family genes in dorsoventral patterning of the vertebrate nervous system
}

\author{
Denise A. Zannino and Charles G. Sagerström*
}

\begin{abstract}
The embryonic vertebrate neural tube is divided along its dorsoventral (DV) axis into eleven molecularly discrete progenitor domains. Each of these domains gives rise to distinct neuronal cell types; the ventral-most six domains contribute to motor circuits, while the five dorsal domains contribute to sensory circuits. Following the initial neurogenesis step, these domains also generate glial cell types-either astrocytes or oligodendrocytes. This DV pattern is initiated by two morphogens-Sonic Hedgehog released from notochord and floor plate and Bone Morphogenetic Protein produced in the roof plate-that act in concentration gradients to induce expression of genes along the DV axis. Subsequently, these DV-restricted genes cooperate to define progenitor domains and to control neuronal cell fate specification and differentiation in each domain. Many genes involved in this process have been identified, but significant gaps remain in our understanding of the underlying genetic program. Here we review recent work identifying members of the Prdm gene family as novel regulators of DV patterning in the neural tube. Many Prdm proteins regulate transcription by controlling histone modifications (either via intrinsic histone methyltransferase activity, or by recruiting histone modifying enzymes). Prdm genes are expressed in spatially restricted domains along the DV axis of the neural tube and play important roles in the specification of progenitor domains, as well as in the subsequent differentiation of motor neurons and various types of interneurons. Strikingly, Prdm proteins appear to function by binding to, and modulating the activity of, other transcription factors (particularly bHLH proteins). The identity of key transcription factors in DV patterning of the neural tube has been elucidated previously (e.g. the $n k x, b H L H$ and pax families), but it now appears that an additional family is also required and that it acts in a potentially novel manner.
\end{abstract}

Keywords: Neural tube, Dorsoventral patterning, Transcription, Neural progenitor, Prdm gene family

\section{Introduction}

Function of the adult central nervous system (CNS) relies on neural circuits to control activity. In order for such circuits to form, neurons must develop at the right time and place of the CNS during embryogenesis. A very elaborate genetic program is responsible for this process along both the head-to-tail (anteroposterior; AP) and back-to-front (dorsoventral; DV) axes of the CNS. In terms of the DV axis, secreted factors (Sonic hedgehog and Bone morphogenetic protein) initially establish gradients that are sensed by progenitor cells in the

\footnotetext{
* Correspondence: charles.sagerstrom@umassmed.edu
Department of Biochemistry and Molecular Pharmacology, University of
Massachusetts Medical School, 364 Plantation St./LRB815, Worcester, MA

* Correspondence: charles.sagerstrom@umassmed.edu
Department of Biochemistry and Molecular Pharmacology, University of
Massachusetts Medical School, 364 Plantation St./LRB815, Worcester, MA

* Correspondence: charles.sagerstrom@umassmed.edu
Department of Biochemistry and Molecular Pharmacology, University of
Massachusetts Medical School, 364 Plantation St./LRB815, Worcester, MA 01605-2324, USA
}

(c) 2015 Zannino and Sagerström. Open Access This article is distributed under the terms of the Creative Commons Attribution 4.0 International License (http://creativecommons.org/licenses/by/4.0/), which permits unrestricted use, distribution, and reproduction in any medium, provided you give appropriate credit to the original author(s) and the source, provide a link to the Creative Commons license, and indicate if changes were made. The Creative Commons Public Domain Dedication waiver (http://creativecommons.org/publicdomain/zero/1.0/) applies to the data made available in this article, unless otherwise stated.

developing neural tube. Depending on their location in the gradient, different progenitor cells initiate the expression of different genes, leading to a pattern of gene expression along the DV axis. These genes subsequently refine the pattern by repressing each other's expression, as well as by activating the expression of additional genes (e.g. neurotransmitters and their receptors) that define different types of neurons (e.g. GABAergic versus glutaminergic). Some genes involved in this process are known, but this review focuses on a new class of genes-the Prdm family-that appears to control gene expression during the formation of neurons along the embryonic DV axis. 


\section{Review}

Prdm family proteins as regulators of gene expression

The Prdm family of proteins has only been recognized relatively recently (reviewed in $[1,2]$ ). Proteins in this family are defined by an N-terminal PR domain, as well as by a varying number of zinc fingers (or, potentially, zinc knuckles). The PR domain was named after its initial identification in the Positive regulatory domain I-binding factor 1 (formerly PRDI-BF1/Blimp-1, now Prdm1) and the Retinoblastoma protein-interacting zinc finger protein 1 (formerly Riz1, now Prdm2) factors [3-6]. While Prdm proteins may function differently in different contexts, emerging evidence suggest that these factors act to regulate gene expression.

The PR domain is related to the SET domain-a catalytic domain with histone lysine methyltransferase (HMT) activity named after the $S$ u(var)3-9, Enhancer of zeste and Trithorax proteins-but the PR domain has diverged significantly from SET domains. In particular, most PR domains lack the $\mathrm{H} / \mathrm{RxxNHxC}$ motif required for methyltransferase activity ([7]; reviewed by [1]). Accordingly, many Prdm proteins appear to lack intrinsic HMTase activity ([8-11] reviewed by [2]). Nevertheless, Prdm2, Prdm8, and Prdm9 have been reported to possess intrinsic HMT activity [2,12-15], although the details of the catalytic mechanism are unclear. Strikingly, Prdm2 and Prdm8 methylate histone H3 on lysine 9 (H3K9), a modification associated with heterochromatin formation and transcriptional repression, whereas Prdm9 directs formation of H3K4me3-a modification associated with transcriptional activity [13-15]. Hence, Prdm proteins may mediate transcriptional activation or repression depending on the nature of their intrinsic HMT activity. Of the Prdm proteins that are enzymatically inactive, many are instead able to recruit histone-modifying enzymes and transcription regulatory factors via protein-protein interactions. Enzymes recruited in this manner include HMTs, the Polcycomb repressive complex 2 (PRC2), protein methyltransferase 5 (Prmt5), lysine specific demethylase 1 (Lsd1), as well as histone deacetylases (HDACs) and histone acetyltransferases (HATs) [10, 16-22] (reviewed in [1, 2]). For example, Prdm1, Prdm5, Prdm6 and Prdm12 all function with the G9a HMT [2, 8-10, 23] and Prdm3 with the Suv39H1 HMT [24] to methylate H3K9 and promote repression. Prdm1 can also function with Prmt5 to methylate H2AR3 and H4R3 [17]. Some Prdm family members require their zinc fingers for recruitment of histone modifying enzymes, while others (such as Prdm1 and Prdm3) also make use of a proline-rich domain [1, 25, 26]. Additionally, transcriptional regulators can be recruited by Prdm proteins, such as the recruitment of Groucho by Prdm1, and the recruitment of CtBP by Prdm2, Prdm3 and Prdm16 ([27-34], reviewed [1]). Hence, Prdm proteins appear to function by modulating gene expression states either directly (via intrinsic HMTase activity), or indirectly (via recruitment of various cofactors).

In order to affect gene expression, Prdm proteins need to access genomic sites in chromatin. Accordingly, Prdm1, Prdm3, Prdm5, Prdm9, Prdm13, Prdm14, and Prdm16 bind DNA directly in a sequence dependent manner via their zinc-finger domains $([9,35-43]$ reviewed in $[1,2])$. While many Prdm proteins have only been tested for DNA binding using in vitro systems, ChIP-seq experiments (chromatin immunoprecipitation using Prdmspecific antibodies followed by deep sequencing) have also identified genomic binding sites for a subset of Prdm factors (Prdm1, Prdm3, Prdm13, and Prdm14) [35, 37, 41, 43-46]. Prdm members that do not bind DNA directly instead appear to utilize binding partners to indirectly associate with DNA, as in the case of Prdm8 accessing DNA by binding together with Bhlhb5 in the developing nervous system [47] and Prdm16 binding with $\mathrm{C} / \mathrm{EBP} \beta$ to promote brown adipose tissue [48]. Again, the zinc finger motifs, as well as prolinerich domains and zinc knuckles, are likely to mediate binding of Prdm proteins to partner proteins to facilitate access to genomic sites. Based on their association with DNA (directly or indirectly), as well as their ability to modify histones (directly or indirectly) and recruit transcriptional regulators, it is likely that Prdm family proteins function to regulate gene expression states. Indeed, Prdm factors appear capable of activating or repressing target genes depending on the specific context-as reported for Prdm1 and Prdm2 [49, 50]. Prdm proteins have been reported to function in numerous settings, including hematopoiesis, adipogenesis and the maintenance of stem cell identity (reviewed by $[1,2]$ ). More recently, several studies have indicated a central role for Prdm factors in the establishment of neuronal cell fates, particularly in the forming hindbrain and spinal cord.

\section{Multiple roles for Prdm proteins in dorsoventral patterning of the neural tube}

Shortly after neural tube closure, the neuroepithelium undergoes extensive transformations, including cell proliferation and specification, to give rise to various neuronal and glial cell types necessary for motor and sensory circuits. This process requires several steps (Fig. 1): First, gene expression is initiated along the dorsoventral (DV) axis of the neural tube in response to morphogen gradients. Second, these domains are refined and discrete gene expression boundaries established by complex regulatory interactions among many genes. Third, distinct neuronal and glial cell types are specified and differentiate from each progenitor domain. Strikingly, emerging data suggest that each of these steps may be under the control, at least in part, of Prdm family genes (Table 1). 


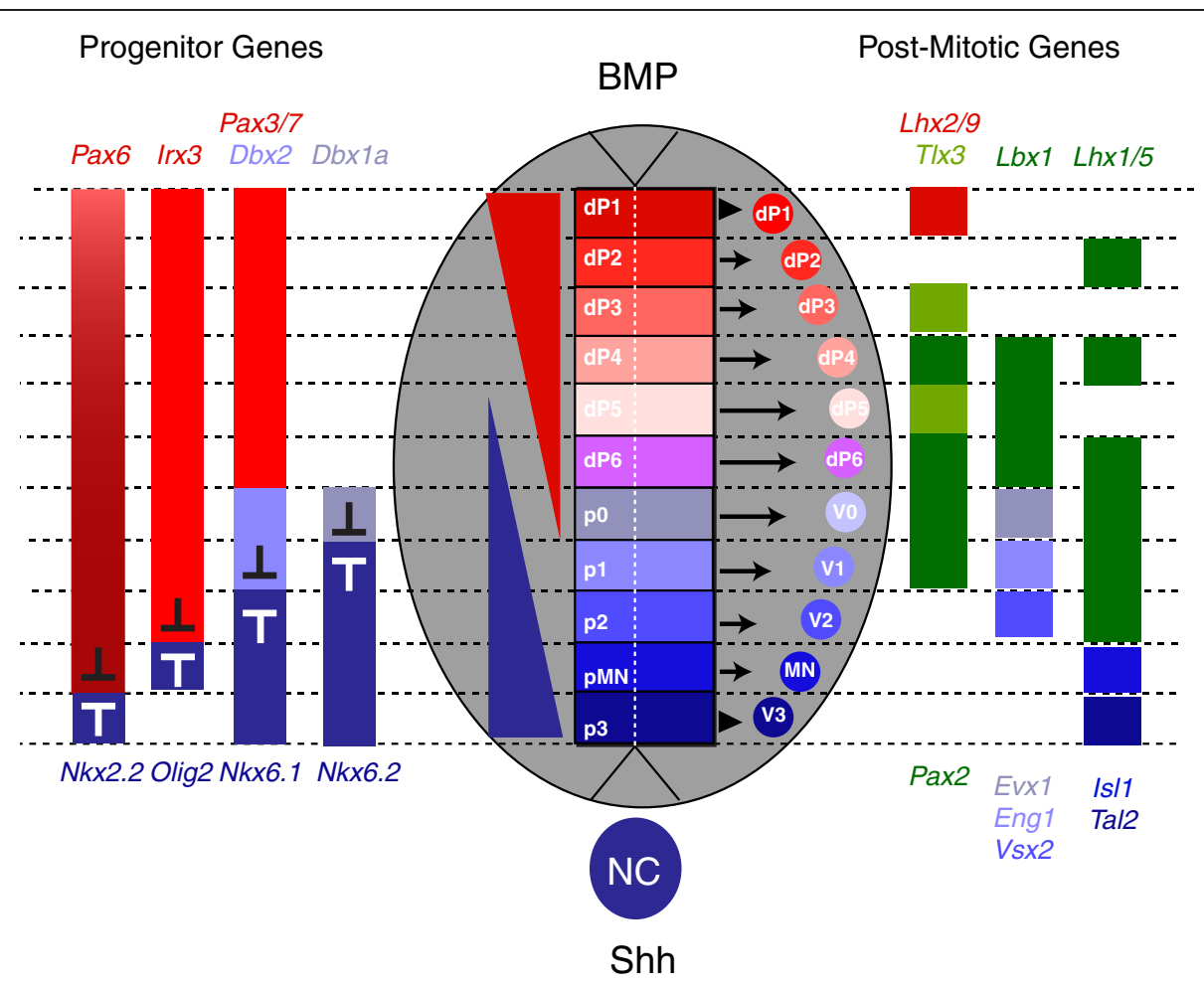

Fig. 1 Schematic diagram of a neural tube cross section. Dorsoventral domains are established by opposing concentration gradients of Shh and BMP (center), which regulate progenitor gene expression (left). The progenitor genes cross-repress each other to establish domain boundaries. Each domain will give rise to a specific cell type that expresses various post-mitotic differentiation genes (right)

Prdm genes are expressed in discrete domains along the DV axis of the neural tube Studies in several vertebrate species have demonstrated a critical role for Sonic Hedgehog (Shh) in patterning of the ventral neural tube and in specification of ventral neuronal cell types. Specifically, Shh is a morphogen secreted from the notochord and floor plate that-along with factors such as Chordin and Noggin that oppose the dorsally expressed BMP morphogen (see below) - induces gene expression in the ventral neural tube (reviewed by [51-53]). This has been demonstrated experimentally by overexpression of Shh in vivo and by application of exogenous Shh to neural tube explants in culture, as well as by inhibiting Shh signaling using neutralizing antibodies or germ line knock outs [54-63]. The Shh gradient subdivides the neural tube into distinct DV progenitor domains by regulating the expression of different genes at different thresholds of Shh signaling ([64-68]; Fig. 1). In particular, Shh activates genes such as $N k x 6.1, N k x 6.2, N k x 2.2$, and Olig2, while it represses genes such as Pax3, Pax6, Pax7, Dbx1, Dbx2 and Irx3 [63-71]. Notably, at least three Prdm genes (Prdm8, Prdm12, and Prdm14; Fig. 2) are expressed in the ventral neural tube. Expression of $\operatorname{Prdm} 8$ is present in the $\mathrm{p} 1, \mathrm{p} 2$ and $\mathrm{pMN}$ domains [72], while Prdm14 is expressed in the pMN domain, specifically in a subset of motor neurons-the Caudal Primary
(CaP) motor neurons [46] - and Prdm12 is expressed in the p1 domain [73, 74]. Based on their expression domains, these three Prdm genes are likely to be regulated by Shh signaling. Indeed, treatment with cyclopamine (a Shh signaling inhibitor), causes a reduction of $\operatorname{Prdm} 12 b$ expression in zebrafish [73]. This suggests that Prdm12b is partially dependent on Shh signaling, as previously reported for other genes expressed in the p1 domain [67], but it remains to be determined if $\operatorname{Prdm} 8$ and $\operatorname{Prdm} 14$ expression is also regulated by Shh signaling.

Similar to Shh signaling in the ventral neural tube, Bone Morphogenetic Proteins (BMPs) function in the dorsal neural tube to pattern progenitor domains and regulate cell specification (Fig. 1). In particular, BMP4, BMP5 and BMP7, as well as the related Gdf7 protein, are expressed in the ectoderm overlaying the neural tube and function in concentration gradients to establish the dP1-6 progenitor domains [75, 76]. As expected, increasing or decreasing the BMP signal in the dorsal neural tube expands or reduces the specification of dorsal cell types, respectively [77-79]. In addition, loss of BMP receptors leads to loss of the $\mathrm{dP} 1$ and a dorsal shift in the dP2 domain [79], while expression of a constitutively active BMP receptor causes a ventral shift in Pax7 expression and an up-regulation of the dP1 expressed Atoh1 (previously Math1) [77]. Notably, Prdm13 is expressed in 
Table 1 Summary of Prdm gene expression and function in the nervous system

\begin{tabular}{|c|c|c|c|c|c|}
\hline $\begin{array}{l}\text { Prdm } \\
\text { gene }\end{array}$ & Nervous system expression & Nervous system function & $\begin{array}{l}\text { Intrinsic HMT } \\
\text { activity }\end{array}$ & $\begin{array}{l}\text { Direct DNA } \\
\text { binding }\end{array}$ & References \\
\hline \multirow[t]{2}{*}{ Prdm1 } & CNS: photoreceptors & CNS: photoreceptor identity & \multirow[t]{4}{*}{ No } & \multirow[t]{2}{*}{ Yes } & \multirow{2}{*}{$\begin{array}{l}{[8,108,109,120} \\
144-147]\end{array}$} \\
\hline & $\begin{array}{l}\text { PNS: prechordal plate, branchial } \\
\text { arches, Rohon-Beard neurons }\end{array}$ & $\begin{array}{l}\text { PNS: branchial arch formation, } \\
\text { Rohon-Beard specification }\end{array}$ & & & \\
\hline \multirow[t]{2}{*}{ Prdm3 } & $\begin{array}{l}\text { CNS: telencephalon, tegmentum, } \\
\text { diencephalon, hindbrain }\end{array}$ & $\begin{array}{l}\text { CNS: olfactory receptor } \\
\text { development }\end{array}$ & & \multirow[t]{2}{*}{ Yes } & \multirow[t]{2}{*}[28,34,120,148]{} \\
\hline & PNS: branchial arches & PNS: craniofacial development & & & \\
\hline Prdm4 & CNS: cerebral cortex & $\begin{array}{l}\text { CNS: in vitro neural stem cell } \\
\text { proliferation and differentiation }\end{array}$ & Yes & & [149-151] \\
\hline \multirow[t]{2}{*}{ Prdm5 } & CNS: ventral spinal cord & \multirow{2}{*}{$\begin{array}{l}\text { PNS: development of the } \\
\text { neuocranium }\end{array}$} & & \multirow[t]{2}{*}{ Yes } & \multirow[t]{2}{*}[9,152,153]{} \\
\hline & PNS: neurocranium & & & & \\
\hline Prdm6 & CNS: spinal cord neurons & & Yes & Yes & {$[74,154]$} \\
\hline Prdm8 & $\begin{array}{l}\text { CNS: telencephalon, retina, tegmentum, } \\
\text { cerebellum, hindbrain and spinal cord }\end{array}$ & $\begin{array}{l}\text { CNS: axonal outgrowth, neocortical } \\
\text { neuron morphology }\end{array}$ & No & Yes & $\begin{array}{l}{[15,47,72,74,120} \\
155]\end{array}$ \\
\hline Prdm10 & PNS: neural crest & CNS: primary dendrite initiation & & & {$[156,157]$} \\
\hline \multirow[t]{2}{*}{ Prdm12 } & $\begin{array}{l}\text { CNS: telencephalon, tegmentum, } \\
\text { cerebellum, midbrain, hindbrain } \\
\text { and spinal cord p1 domain }\end{array}$ & \multirow[t]{2}{*}{$\begin{array}{l}\text { CNS: formation of V1 interneurons, } \\
\text { pain perception and sensory neuron } \\
\text { development }\end{array}$} & & & \multirow[t]{2}{*}{$\begin{array}{l}{[73,74,81,120,158,} \\
159]\end{array}$} \\
\hline & PNS: cranial placodes & & & & \\
\hline Prdm13 & $\begin{array}{l}\text { CNS: tegmentum, hindbrain, spinal } \\
\text { cord, retina }\end{array}$ & $\begin{array}{l}\text { CNS: GABAergic interneuron } \\
\text { development }\end{array}$ & & Yes & {$[43,74,80,120]$} \\
\hline Prdm14 & CNS: ventral spinal cord & $\begin{array}{l}\text { CNS: CaP motor neuron axonal } \\
\text { projection }\end{array}$ & & Yes & {$[46,74,120]$} \\
\hline \multirow[t]{2}{*}{ Prdm16 } & $\begin{array}{l}\text { CNS: forebrain, telencephalon, } \\
\text { hindbrain, retina }\end{array}$ & CNS: olfactory neuron development & \multirow[t]{2}{*}{ Yes } & \multirow[t]{2}{*}{ Yes } & \multirow[t]{2}{*}[28,34,74,120,160]{} \\
\hline & PNS: craniofacial structures & PNS: craniofacial development & & & \\
\hline
\end{tabular}

Blank cells indicate categories were information is lacking in the literature. The list of expression domains and functions is not exhaustive

the dorsal neural tube in the dP2-dP6 domains ([43, 80]; Fig. 2), suggesting that it may be regulated by BMP. However, Prdm13 has been shown to act downstream of Ptf1a, so BMP may function indirectly to control Prdm13 expression [43, 80]. Notably, the expression of $\operatorname{Prdm} 12 b$ in the $\mathrm{p} 1$ domain may also be sensitive to $\mathrm{BMP}$ signaling since the $\mathrm{p} 0$ and $\mathrm{p} 1$ domains are dependent on both Shh and BMP signaling (e.g. Evx1 and $E n 1$ expression in $\mathrm{p} 0 / \mathrm{p} 1$ is reduced upon introduction of a constitutively active BMP receptor; [77]; reviewed by [52]). Accordingly, $\operatorname{Prdm12}$ is regulated by BMP signaling outside the neural tube, such as in preplacodal ectoderm [81].

Factors in addition to Shh and BMP are also involved in establishing progenitor domains in the neural tube. For instance, ventrally expressed BMP inhibitors (Chordin, Noggin and Follistatin) are required to suppress BMP signaling, thereby promoting the formation of ventral progenitor domains [82-87]. FGF signaling also promotes ventral fates by repressing Pax6, Irx3, Dbx 1 and $D b x 2$ [88-90]. In contrast, Wnt1 and Wnt3a expressed in the roof plate are required for formation of dorsal progenitor domains (reviewed in $[52,53]$ ), as loss of Wnt signaling leads to reduction in $\mathrm{dP} 1$ and $\mathrm{dP} 2$ neurons, with excess formation of $\mathrm{dP} 3$ neurons [91]. Retinoic acid (RA) is also released from the roof plate [92] to promote formation of dorsal progenitor domains. Accordingly, reduced RA signaling leads to dorsal expansion of ventral genes such as $N k x 6.1$ and $N k x 2.2$ $[90,93,94]$ - although this may be a partially indirect effect mediated by loss of Pax6 [52] - and reduced expression of dorsal genes such as Bmp4/7, Msx2, Pax3/ 7, Wnt1/3a, Pax6 and Irx3 [90, 94-97]. Several Prdm genes are regulated by these pathways outside of the neural tube. For instance, expression of Prdm12 in Xenopus lateral pre-placodal ectoderm is reduced when Wnt3a is over-expressed [81] and Prdm14 expression in primordial germ cell specification may be activated when T-Brachyury-a downstream target of Wnt3abinds to an enhancer at the Prdm14 gene [98]. Furthermore, RA treatment induces expression of Prdm12 in cell lines [23]. Hence, it is plausible that Prdm gene expression is induced by Fgf, Wnt and/or RA signaling also in dorsoventral patterning of the neural tube. 


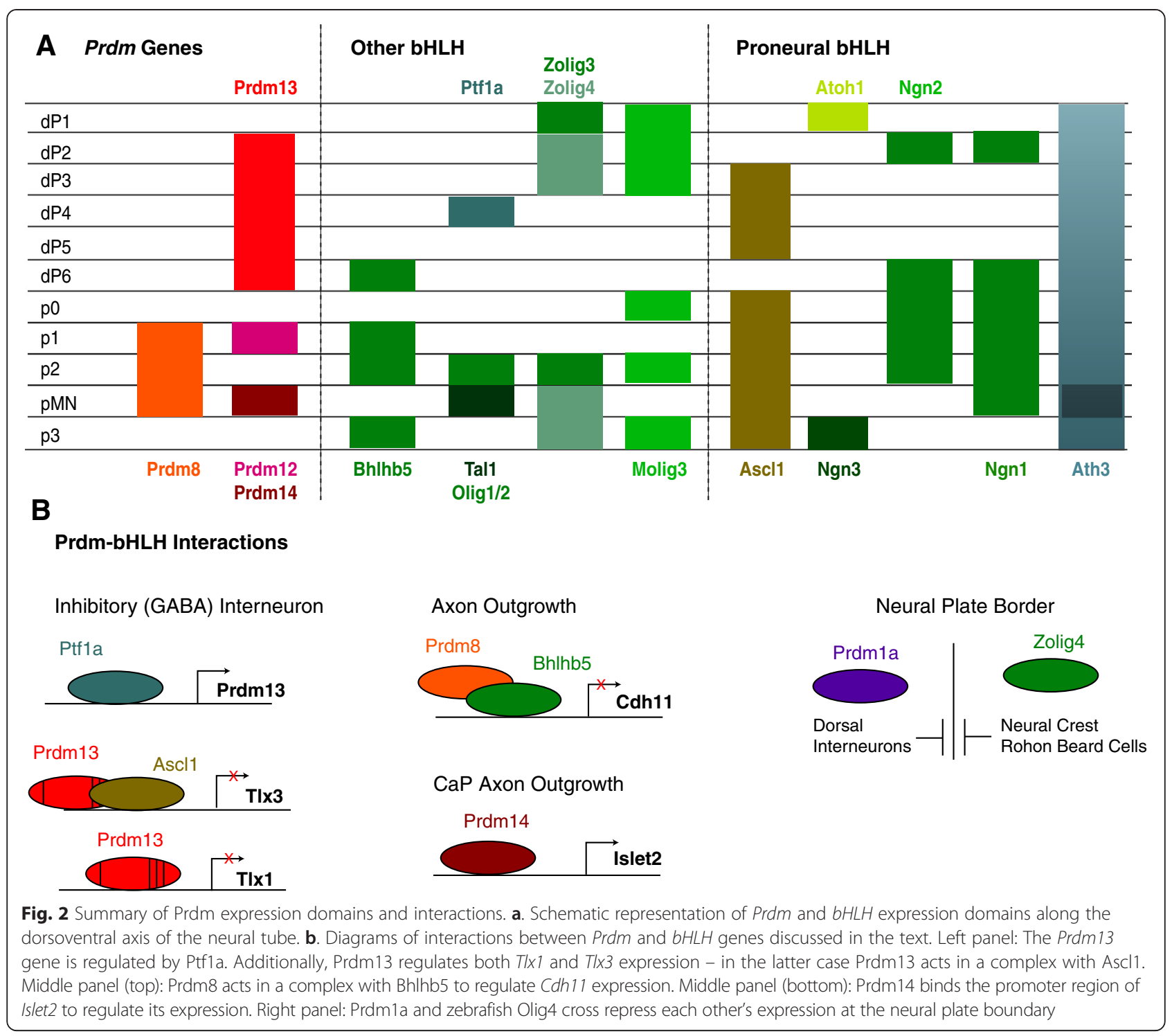

Prdm genes are involved in mutually repressive interactions between gene expression domains The distinct boundaries observed between progenitor domains in the neural tube are established by cross-repressive interactions between adjacent gene expression domains (Fig. 1). Several mutually repressive pairs of transcription factors have been identified, including Pax6/Nkx2.2, Dbx2/Nkx6.1 and Irx3/Olig2 ([64, 66, 68-70, 99-102]; reviewed in [53]). For instance, Irx3 and Olig2 repress each other's expression, thereby setting up the $\mathrm{p} 2 / \mathrm{pMN}$ boundary [69, 102]. Accordingly, knock-out of Olig2 causes a ventral expansion of Irx3 and leads the pMN domain to adopt more dorsal characteristics. Hence, this domain gives rise to V2 interneurons and astrocytes instead of the motor neurons and oligodendrocytes that normally arise from the pMN domain [102]. Given the expression of $\mathrm{Prdm}$ genes in discrete domains along the dorsoventral axis of the neural tube, it is likely that Prdm genes also engage in mutually repressive interactions. For instance, $\operatorname{Prdm} 12 b$ is expressed in the $\mathrm{p} 1$ progenitor domain and shares an expression boundary with $N k x 6.1$ - which is expressed in the $\mathrm{p} 2, \mathrm{pMN}$ and $\mathrm{p} 3$ domains - at the $\mathrm{p} 1 / \mathrm{p} 2$ border. Notably, loss of Prdm12b function leads to ectopic expression of $N k x 6.1$ dorsally [73], suggesting that Prdm12b represses $N k x 6.1$ expression. However, it is not clear if this effect is direct, nor is it clear if $N k x 6.1$ reciprocally represses $\operatorname{Prdm} 12 b$ expression. Furthermore, zebrafish Olig4 (Olig3 in mouse) is expressed in the $\mathrm{dP} 1-3$ domains, where it is required for the specification of dorsal interneurons [103-105], whereas Prdmla is expressed adjacent to Olig4 at the neural plate border [106]. Knockdown of Olig4 results in a severe reduction, or loss, of dorsal interneurons and a corresponding increase in cell types normally specified 
by $\operatorname{Prdm1a-neural~crest~cells~and~Rohon-Beard~cells~}$ [103, 105, 107-109]. Further studies confirmed that Prdm1a represses Olig4 expression, and vice versa, to establish and maintain the neural plate border and interneuron domains [106]. As Prdm gene function in the neural tube becomes analyzed more closely, it is likely that additional cases of reciprocal repression will be identified.

\section{Prdm genes regulate neuronal specification and} differentiation in the neural tube Through their roles as regulators of gene expression, Prdm family proteins affect the specification and differentiation of neuronal subtypes from various progenitor domains.

\section{$\operatorname{Prdm12b}$ is required for the formation of $\mathrm{V} 1$}

interneurons Prdm 12 was originally described in chronic myeloid leukemia as a gene located in a deleted region on chromosome 9 [110, 111]. Prdm12 also plays a role controlling proliferation in various cell lines [23]. Expression of $\operatorname{Prdm} 12$ within the developing CNS was first described in the mouse, with expression domains identified in the ventricular zone of the telencephalon, as well as in distinct domains within the hindbrain and spinal cord [74]. A similar pattern is observed in the zebrafish neural tubespecifically, $\operatorname{Prdm} 12 b$ expression is limited to the $\mathrm{p} 1$ domain in the hindbrain and spinal cord, as well as to cells adjacent to the exit points of the ventral motor roots [73]. The spinal cord $\mathrm{p} 1$ domain gives rise to V1 interneurons, a class of inhibitory glycinergic interneurons that function to regulate motor circuits controlling trunk and tail musculature [112-117] and reviewed ([118]). V1 interneurons are defined by their expression of the Eng1 gene [64, 115]. Disruption of $\operatorname{Prdm} 12 b$ function leads to loss of Eng1b positive cells in zebrafish hindbrain and spinal cord, suggesting that $\operatorname{Prdm} 12 b$ is required for V1 interneuron formation. Strikingly, fish lacking $\operatorname{Prdm} 12 b$ function, and therefore also lacking V1 interneurons, display a defective escape response. In particular, when control fish are touched on the head, they bend their body into a single C-turn-bringing their head adjacent to the tail and orienting the head away from the stimulus-and then swim away. In contrast, Prdm12b-deficient fish exhibit multiple C-turns, display a longer response time with less productive swimming movements, and take longer between alternating body bends [73]. Hence, $\operatorname{Prdm} 12 b$ is required for the formation of the p1 domain and p1-derived neurons, although it remains unclear if the behavioral defect results from the loss of V1 interneurons in spinal motor circuits, or from the loss of some other class of p1derived neurons in the hindbrain.
Prdm14 controls formation of motor neuron axons The pMN domain gives rise to motor neurons in a process that appears to require Prdm14. In zebrafish, four types of primary motor neurons (one of which is transient) are generated in the spinal cord, including $\mathrm{CaP}$ (caudal primary), MiP (middle primary), RoP (rostal primary) and $\mathrm{VaP}$ (variable primary). A zebrafish mutant for Prdm14, named short lightning (slg), was identified in a gene-trap screen using the Tol2 transposon system when a transposon inserted into the Prdm14 locus [46]. Strikingly, loss of Prdm14 does not affect the specification of motor neurons. Instead, CaP motor neurons in slg embryos display shortened axons and such embryos exhibit impaired escape responses and diminished swimming movements [46]. Prdm14 binds DNA via its zinc finger domain [41] and has been shown to occupy binding sites upstream of the Islet 2 gene [46], which is required for the development of motor neurons. Notably $\operatorname{Prdm14}$ is expressed in $\mathrm{CaP}$ and VaP motor neurons, but not in MiP or RoP motor neurons. Similarly, Islet 2 is restricted to $\mathrm{CaP}$ and $\mathrm{VaP}$, while Islet1 is maintained in $\mathrm{MiP}$ and RoP, motor neurons. Hence, Prdm14 and Islet 2 are co-expressed in $\mathrm{CaP}$ motor neurons, explaining why the defects in slg mutants are restricted to this cell type. Interestingly, Prdm14 and Islet 2 are also co-expressed in Rohon-Beard cells (a class of primary sensory neurons found in zebrafish), but Prdm14 does not regulate Islet 2 expression in this cell population. Instead, another Prdm gene, $\operatorname{Prdm1a}$, is expressed in Rohon-Beard cells where it regulates Islet2 $[46,119]$. Thus, Prdm14 regulates Islet 2 in $\mathrm{CaP}$ motor neurons and Prdm1a regulates Islet 2 in Rohon-Beard cells, illustrating two examples of Prdm genes controlling neuronal cell fate. We note that Prdm8 is also expressed in the pMN domain, but apparently not in precursors of motor neurons [72] and it is therefore unlikely to control motor neuron formation.

Prdm13 controls formation of GABAergic neurons $\operatorname{Prdm} 13$ is expressed in the $\mathrm{dP} 6-\mathrm{dP} 2$ progenitor domains of the dorsal spinal cord $[34,43,74,80,120]$. Prdm13 is both necessary and sufficient to promote differentiation of inhibitory (GABAergic) neurons over excitatory (glutamatergic) neurons $[43,80]$. Specifically, $\operatorname{Prdm} 13$ represses expression of $T l \times 1$ and $T l x 3$ (excitatory lineage genes) by directly binding to their regulatory regions, as well as by binding to the Ascl1 transcription factor and inhibiting its ability to activate Tlx 3 expression (see below for further details; [43]). Furthermore, Prdm13 blocks the ability of Neurogenin2 (another transcription factor involved in neuronal specification; $[121,122])$ to activate transcription of $T l x 3$ [80].

Prdm8 controls targeting of projection neurons in the telencephalon $\operatorname{Prdm} 8$ is expressed at multiple sites 
of the CNS, including the dorsal telencephalon and the pMN-p1 domains of the hindbrain and spinal cord. Loss of function analyses in the mouse revealed that $\operatorname{Prdm} 8$ is required for proper targeting of several major axon tracts (corticospinal tract, hippocampal commissure, anterior commissure and corpus callosum), apparently by cooperating with the Bhlhb5 gene (see below for further details; [47]).

\section{Prdm family proteins form complexes with other transcription factors to control gene expression}

While it appears clear that Prdm family proteins act as transcription factors to control neuronal differentiation, it remains unclear precisely how they function. For instance, Prdm12b regulates expression of Eng1b in V1 interneurons, but it is not clear that Prdm12b binds DNA. Furthermore, Prdm1a, Prdm12b, Prdm13 and Prdm14 all control transcription, but these proteins do not all contain recognizable transcription regulatory domains. The simplest explanation would be that Prdm proteins act in complexes with other regulatory factors. Indeed, there are now several reports of Prdm proteins interacting physically with other transcription factors in larger complexes.

Prdm13 interacts with Ascl1 to promote formation of GABAergic neurons As discussed, Prdm13 is expressed in the dP2-dP6 progenitor domains [34, 43, 74, 80, 120], but appears to function primarily in $\mathrm{dP} 4$. In this region of the neural tube, several bHLH proteins function together with various binding partners in a combinatorial code to specify individual cell fates (reviewed by [123]). Specifically, dP1, dP2, dP3 and dP5 give rise to excitatory (glutamatergic) neurons, while $\mathrm{dP} 4$ gives rise to inhibitory (GABAergic) neurons. The bHLH transcriptional activators Ascl1, expressed in dP3-5, and Ptf1a, expressed only in $\mathrm{dP} 4$, are required for the formation of excitatory versus inhibitory interneurons in $\mathrm{dP} 3-\mathrm{dP} 5$, such that Ascl1 alone drives expression of the $T l x 1$ and $T l x 3$ genes to promote excitatory interneuron fates in $\mathrm{dP} 3$ and $\mathrm{dP} 5$, while coexpression of Ptfla with Ascl1 in dP4 promotes inhibitory interneuron fates by repressing $T l x 1$ and $T l x 3$ transcription and promoting expression of $\operatorname{Pax} 2$ and $L b x 1$ [122, 124-133]. Strikingly, it appears that Ptf1a acts via Prdm13 in dP4 to switch Ascl1 from a transcriptional activator to a repressor. In particular, Ptf1a directly activates Prdm13 expression in $\mathrm{dP} 4$ and Prdm13 binds the same regulatory regions as Ascl1 at the Tlx 3 gene $[43,80]$. Furthermore, Prdm13:Ascl1-containing complexes can be detected by co-immunoprecipitation [43], suggesting that such complexes regulate $T l x 3$ expression. Prdm 13 also interferes with the ability of Neurog2 to activate Tlx3 [80], but it is not clear if this involves the formation of a complex between $\operatorname{Prdm} 13$ and
Neurog2. Lastly, Prdm13 represses Tlx1 in the absence of Ascl1 [43], suggesting that Prdm13 may also be a transcriptional repressor in its own right, or that it may interact with other factors in the regulation of Tlx1.

Prdm13 has been reported to exhibit methyltransferase activity [80], but it is not clear if this activity is intrinsic to Prdm13, or the result of a co-purifying factor. Indeed, the Prdm13 PR domain-the domain with sequence similarity to methyltransferases-is not required for its ability to repress $T l x 1$ and $T l x 3$ [43], indicating that intrinsic methyltransferase activity is unlikely to be required for Prdm13 to function as a repressor. In contrast, the $\operatorname{Prdm} 13$ zinc fingers are required for it to function as a repressor [43].

Notably, Prdm13 expression overlaps with the expression domains of other bHLH genes and it is therefore possible that additional Prdm13:bHLH complexes may form. For instance, Prdm13 expression overlaps with Olig3 (Olig4 in zebrafish) expression in $\mathrm{dP} 2$ and $\mathrm{dP} 3$ $[104,105,134,135]$. The dP2 and dP3 domains give rise to Class A interneurons and loss of Olig3 function respecifies them to produce dP4 interneurons [104, 135]. Given the physical interaction between Prdm13 and the bHLH factor Ascl1 in dP4, this raises the possibility that Prdm13 and Olig3 could function as a complex in the specification of $\mathrm{dP} 2$ and $\mathrm{dP} 3$, but this remains to be explored.

Prdm8 acts in a complex with Bhlhb5 to control neural circuit assembly The Bhlhb5 gene is closely related to the Olig subfamily of bHLH genes, but is expressed in postmitotic neurons-particularly in excitatory neurons of the dorsal telencephalon [136, 137, 138]. Similar to the Olig proteins, Bhlhb5 appears to act as a transcriptional repressor $[139,140]$. Bhlhb5 mutant mice exhibit axonal projection defects such that axons originating in the dorsal telencephalon fail to reach their targets (Joshi 2008). This phenotype is shared with Prdm8 mutant mice such that both mutants exhibit mistargeting of the main fiber tracts connecting the cerebral hemispheres [47]. Importantly, Bhlhb5 and Prdm8 are co-expressed in many populations of differentiating neurons, including the dorsal telencephon, indicating that they may function together. Indeed, further analyses revealed that Bhlhb5 and Prdm8 proteins interact in a coimmunoprecipitation assay and that the two proteins cooccupy promoter elements in vivo, as defined by ChIP analysis [47]. Strikingly, the same set of target genes is up-regulated in Bhlhb5 and Prdm8 mutants, though the mutants differ such that Bhlhb5 can bind targets in the absence of Prdm8-but not vice versa. Hence, it appears that Bhlhb5 binds DNA directly (most likely as a homodimer via a canonical E-box motif), but cannot repress target genes in the absence of $\operatorname{Prdm} 8$, while $\operatorname{Prdm} 8$ is a 
repressor that cannot access target genes in the absence of Bhlhb5. Among the Bhlhb5/Prdm8 target genes, Cdh11 is expressed in several intermediate targets of the corticospinal projections and is up-regulated in Bhlhb5 and $\operatorname{Prdm} 8$ mutant mice. Analysis of Bhlhb5/Cdh11 double mutants, which allows reduction of $C d h 11$ expression in the Bhlhb5 mutant background, revealed that axonal targeting was partially rescued [47], suggesting that Bhlhb5/Prdm8 regulates neuronal circuit formation at least in part by controlling $C d h 11$ expression levels.

Bhlhb5 and Prdm8 are co-expressed at other sites in the CNS. For instance, both genes are expressed in the spinal cord p2 domain [72, 141, 142] and Bhlhb5 has been implicated in specifying V2a over V2b interneurons [141], suggesting that Bhlhb5:Prdm8 complexes may act also in V2a differentiation. Furthermore, Bhlhb5 expression overlaps with the expression of other Prdm genes-such as Prdm12 in the p1 domain and Prdm13 in the AP6 domain-and Bhlhb5 is involved in the specification of interneurons from those domains [141, 142]. While this suggests potential interactions for Prdm12 and Prdm13 with Bhlhb5, this remains to be tested.

\section{Conclusions}

\section{Emerging principles for Prdm function in the developing} CNS

Embryogenesis is replete with transcription factor "codes" and networks working in concert to specify and differentiate various cell types. Here we have reviewed the function of Prdm genes expressed within the neural tube, discussed the known interactions between bHLH transcription factors and Prdm family members, as well as proposed additional processes where members of these families are expressed, function, and may directly interact. From this review, some general principles are beginning to emerge. First, many Prdm family genes function in the developing CNS. To date, five Prdm genes (Prdm1a, Prdm8, $\operatorname{Prdm12b}$, Prdm13 and Prdm14) have been shown to control CNS development. Second, Prdm genes are involved in multiple aspects of CNS development. $\operatorname{Prdm} 12 b$ and $\operatorname{Prdm} 1 a$ play roles in early patterning by controlling the formation of expression domain boundaries (Prdm $12 b$ controls the $\mathrm{p} 1 / \mathrm{p} 2$ boundary and Prdm1a the neural plate border; [73, 106]), while $\operatorname{Prdm} 13$ acts on cell fate decisions to control the formation of inhibitory (GABAergic) over excitatory (glutamatergic) neurons $[43,80]$. In contrast, Prdm14 acts during motor neuron maturation to control proper axonal outgrowth [46] and $\operatorname{Prdm} 8$ acts to control appropriate axonal targeting during neural circuit formation [47]. Third, Prdm proteins function in complexes with other transcription factors. In particular, Prdm8 functions by forming a repressor complex with Bhlhb5 in the dorsal telencephalon [47] and Prdm13 interacts with Ascl1 to promote formation of GABAergic neurons $[43,80]$. These findings suggest a general model where Prdm family members function in multi-protein transcription regulatory complexes that control diverse aspects of neural development-from the patterning of expression domains and cell specification to axonal projections and circuit formation.

Since the Prdm family is still relatively poorly characterized and new members continue to be added, it is likely that additional Prdm genes are involved in CNS development-or that known Prdm genes will have additional functions. As discussed, Prdm13 physically interacts with the bHLH protein Ascl1 in the dP4 domain [43], but $\operatorname{Prdm13}$ is also co-expressed with another bHLH protein-Olig3 (Olig4 in zebrafish)-in the dP1dP3 domains, suggesting that Prdm13:Olig3(4) complexes may act in dP1-dP3. Similarly, both Prdm12b and bHLHb5 are expressed in the $\mathrm{p} 1$ domain and play roles in V1 interneuron specification [73, 74, 141, 142], indicating they might interact in a complex. Perhaps even more compelling, Bhlhb5 and Prdm8-that are known to interact in the telencephalon-are also co-expressed in the $\mathrm{p} 2$ domain (where Bhlhb5 has a known role in V2a interneuron specification [141, 142]) suggesting that they may act together in a complex also in the $\mathrm{p} 2$ domain.

There are several gene families with important roles in early neural development. In particular, the bHLH, Pax, Dbx, and Nkx families regulate neuronal cell fate specification and differentiation [52, 53, 123, 143]. The data reviewed here demonstrate that $P r d m$ genes also have essential functions in CNS development, thereby placing the Prdm family alongside these other gene families as key regulators of neural development. Strikingly, there appears to be a particularly close relationship between the bHLH and Prdm families (Fig. 2b) with Prdm proteins having the ability to modulate bHLH protein function via the formation of protein complexes (e.g. Prdm8 binding with Bhlhb5 [47] and Prdm13 binding with Ascl1 [43]).

\section{Abbreviations}

CNS: Central nervous system; DV: Dorsoventral; AP: Anteroposterior; HMT: Histone methyltransferase; HDAC: Histone deacetylase; HAT: Histone acetyl transferase; ChIP: Chromatin immunoprecipitation; CaP: Caudal primary; MiP: Middle primary; RoP: Rostral primary; VaP: Variable primary.

\section{Competing interests}

There are no competing interests.

\section{Author contributions}

DZ and CS reviewed the published literature and wrote the manuscript. Both authors read and approved the final manuscript.

\section{Acknowledgements}

This work was supported by NIH grant HD065081 to CS.

Received: 10 August 2015 Accepted: 13 October 2015

Published online: 24 October 2015 


\section{References}

1. Hohenauer T, Moore AW. The Prdm family: expanding roles in stem cells and development. Development. 2012;139(13):2267-82.

2. Fog CK, Galli GG, Lund AH. PRDM proteins: important players in differentiation and disease. Bioessays. 2012;34(1):50-60.

3. Buyse IM, Shao G, Huang S. The retinoblastoma protein binds to RIZ, a zincfinger protein that shares an epitope with the adenovirus E1A protein. Proc Natl Acad Sci U S A. 1995;92(10):4467-71.

4. Turner Jr CA, Mack DH, Davis MM. Blimp-1, a novel zinc finger-containing protein that can drive the maturation of B lymphocytes into immunoglobulin-secreting cells. Cell. 1994;77(2):297-306.

5. Keller AD, Maniatis T. Identification and characterization of a novel repressor of beta-interferon gene expression. Genes Dev. 1991;5(5):868-79.

6. Huang S. Blimp-1 is the murine homolog of the human transcriptional repressor PRDI-BF1. Cell. 1994;78(1):9.

7. Rea S, Eisenhaber F, O'Carroll D, Strahl BD, Sun ZW, Schmid M, et al. Regulation of chromatin structure by site-specific histone $\mathrm{H} 3$ methyltransferases. Nature. 2000;406(6796):593-9.

8. Gyory I, Wu J, Fejer G, Seto E, Wright KL. PRDI-BF1 recruits the histone H3 methyltransferase G9a in transcriptional silencing. Nat Immunol. 2004:5(3):299-308.

9. Duan Z, Person RE, Lee HH, Huang S, Donadieu J, Badolato R, et al. Epigenetic regulation of protein-coding and microRNA genes by the Gfi1interacting tumor suppressor PRDM5. Mol Cell Biol. 2007;27(19):6889-902.

10. Davis CA, Haberland M, Arnold MA, Sutherland LB, McDonald OG, Richardson JA, et al. PRISM/PRDM6, a transcriptional repressor that promotes the proliferative gene program in smooth muscle cells. Mol Cell Biol. 2006;26(7):2626-36.

11. Zhang Y, Stehling-Sun S, Lezon-Geyda K, Juneja SC, Coillard L, Chatterjee G, et al. PR-domain-containing Mds1-Evi1 is critical for long-term hematopoietic stem cell function. Blood. 2011:118(14):3853-61.

12. Derunes C, Briknarova K, Geng L, Li S, Gessner CR, Hewitt K, et al. Characterization of the PR domain of RIZ1 histone methyltransferase. Biochem Biophys Res Commun. 2005;333(3):925-34.

13. Kim KC, Geng L, Huang S. Inactivation of a histone methyltransferase by mutations in human cancers. Cancer Res. 2003;63(22):7619-23.

14. Hayashi K, Yoshida K, Matsui Y. A histone H3 methyltransferase controls epigenetic events required for meiotic prophase. Nature. 2005;438(7066):374-8.

15. Eom GH, Kim K, Kim SM, Kee HJ, Kim JY, Jin HM, et al. Histone methyltransferase PRDM8 regulates mouse testis steroidogenesis. Biochem Biophys Res Commun. 2009;388(1):131-6.

16. Su ST, Ying HY, Chiu YK, Lin FR, Chen MY, Lin Kl. Involvement of histone demethylase LSD1 in Blimp-1-mediated gene repression during plasma cell differentiation. Mol Cell Biol. 2009:29(6):1421-31.

17. Ancelin K, Lange UC, Hajkova P, Schneider R, Bannister AJ, Kouzarides T, et al. Blimp1 associates with Prmt5 and directs histone arginine methylation in mouse germ cells. Nat Cell Biol. 2006;8(6):623-30.

18. Yu J, Angelin-Duclos C, Greenwood J, Liao J, Calame K. Transcriptional repression by blimp-1 (PRDI-BF1) involves recruitment of histone deacetylase. Mol Cell Biol. 2000;20(7):2592-603.

19. Alliston T, Ko TC, Cao Y, Liang YY, Feng XH, Chang C, et al. Repression of bone morphogenetic protein and activin-inducible transcription by Evi-1. J Biol Chem. 2005;280(25):24227-37.

20. Yoshimi A, Goyama S, Watanabe-Okochi N, Yoshiki Y, Nannya Y, Nitta E, et al. Evi1 represses PTEN expression and activates PI3K/AKT/mTOR via interactions with polycomb proteins. Blood. 2011;117(13):3617-28.

21. Chittka A, Arevalo JC, Rodriguez-Guzman M, Perez P, Chao MV, Sendtner M. The p75NTR-interacting protein SC1 inhibits cell cycle progression by transcriptional repression of cyclin E. J Cell Biol. 2004;164(7):985-96.

22. Takahata M, Inoue $Y$, Tsuda H, Imoto I, Koinuma D, Hayashi M, et al. SKI and MEL1 cooperate to inhibit transforming growth factor-beta signal in gastric cancer cells. J Biol Chem. 2009;284(5):3334-44.

23. Yang CM, Shinkai Y. Prdm12 is induced by retinoic acid and exhibits antiproliferative properties through the cell cycle modulation of P19 embryonic carcinoma cells. Cell Struct Funct. 2013;38(2):195-204.

24. Cattaneo F, Nucifora G. EVI1 recruits the histone methyltransferase SUV39H1 for transcription repression. J Cell Biochem. 2008;105(2):344-52.

25. Huang S, Shao G, Liu L. The PR domain of the Rb-binding zinc finger protein $\mathrm{RIZ1}$ is a protein binding interface and is related to the SET domain functioning in chromatin-mediated gene expression. J Biol Chem. 1998;273(26):15933-9.
26. Bartholomew C, Kilbey A, Clark AM, Walker M. The Evi-1 proto-oncogene encodes a transcriptional repressor activity associated with transformation. Oncogene. 1997; 14(5):569-77.

27. Ren B, Chee KJ, Kim TH, Maniatis T. PRDI-BF1/Blimp-1 repression is mediated by corepressors of the Groucho family of proteins. Genes Dev. 1999;13(1):125-37.

28. Endo K, Karim MR, Taniguchi H, Krejci A, Kinameri E, Siebert M, et al. Chromatin modification of Notch targets in olfactory receptor neuron diversification. Nat Neurosci. 2012;15(2):224-33.

29. Izutsu K, Kurokawa M, Imai Y, Maki K, Mitani K, Hirai H. The corepressor CtBP interacts with Evi-1 to repress transforming growth factor beta signaling. Blood. 2001;97(9):2815-22.

30. Kajimura S, Seale P, Tomaru T, Erdjument-Bromage H, Cooper MP, Ruas JL, et al. Regulation of the brown and white fat gene programs through a PRDM16/CtBP transcriptional complex. Genes Dev. 2008;22(10):1397-409.

31. Nishikata I, Nakahata S, Saito Y, Kaneda K, Ichihara E, Yamakawa N, et al. Sumoylation of MEL1S at lysine 568 and its interaction with CtBP facilitates its repressor activity and the blockade of G-CSF-induced myeloid differentiation. Oncogene. 2011;30(40):4194-207.

32. Palmer S, Brouillet JP, Kilbey A, Fulton R, Walker M, Crossley M, et al. Evi-1 transforming and repressor activities are mediated by CtBP co-repressor proteins. J Biol Chem. 2001;276(28):25834-40.

33. Quinlan KG, Nardini M, Verger A, Francescato P, Yaswen $P$, Corda D, et al. Specific recognition of ZNF217 and other zinc finger proteins at a surface groove of C-terminal binding proteins. Mol Cell Biol. 2006;26(21):8159-72.

34. Van Campenhout $C$, Nichane M, Antoniou A, Pendeville H, Bronchain OJ, Marine JC, et al. Evi1 is specifically expressed in the distal tubule and duct of the Xenopus pronephros and plays a role in its formation. Dev Biol. 2006;294(1):203-19.

35. Bard-Chapeau EA, Jeyakani J, Kok CH, Muller J, Chua BQ, Gunaratne J, et al. Ecotopic viral integration site 1 (EVI1) regulates multiple cellular processes important for cancer and is a synergistic partner for FOS protein in invasive tumors. Proc Natl Acad Sci U S A. 2012;109(6):2168-73.

36. Baudat F, Buard J, Grey C, Fledel-Alon A, Ober C, Przeworski M, et al. PRDM9 is a major determinant of meiotic recombination hotspots in humans and mice. Science. 2010;327(5967):836-40.

37. Chia NY, Chan YS, Feng B, Lu X, Orlov YL, Moreau D, et al. A genome-wide RNAi screen reveals determinants of human embryonic stem cell identity. Nature. 2010;468(7321):316-20.

38. Delwel R, Funabiki T, Kreider BL, Morishita K, Ihle JN. Four of the seven zinc fingers of the Evi-1 myeloid-transforming gene are required for sequencespecific binding to GA(C/T)AAGA(T/C)AAGATAA. Mol Cell Biol. 1993:13(7):4291-300.

39. Funabiki T, Kreider BL, Ihle JN. The carboxyl domain of zinc fingers of the Evi-1 myeloid transforming gene binds a consensus sequence of GAAGATGAG. Oncogene. 1994;9(6):1575-81.

40. Kuo TC, Calame KL. B lymphocyte-induced maturation protein (Blimp)-1, IFN regulatory factor (IRF)-1, and IRF-2 can bind to the same regulatory sites. J Immunol. 2004;173(9):5556-63.

41. Ma Z, Swigut T, Valouev A, Rada-Iglesias A, Wysocka J. Sequence-specific regulator Prdm14 safeguards mouse ESCs from entering extraembryonic endoderm fates. Nat Struct Mol Biol. 2011;18(2):120-7.

42. Seale P, Kajimura S, Yang W, Chin S, Rohas LM, Uldry M, et al. Transcriptional control of brown fat determination by PRDM16. Cell Metab. 2007;6(1):38-54.

43. Chang JC, Meredith DM, Mayer PR, Borromeo MD, Lai HC, Ou YH, et al. Prdm13 mediates the balance of inhibitory and excitatory neurons in somatosensory circuits. Dev Cell. 2013;25(2):182-95.

44. Doody GM, Care MA, Burgoyne NJ, Bradford JR, Bota M, Bonifer C, et al. An extended set of PRDM1/BLIMP1 target genes links binding motif type to dynamic repression. Nucleic Acids Res. 2010;38(16):5336-50. doi:gkq268.

45. von Hofsten J, Elworthy S, Gilchrist MJ, Smith JC, Wardle FC, Ingham PW. Prdm1- and Sox6-mediated transcriptional repression specifies muscle fibre type in the zebrafish embryo. EMBO Rep. 2008;9(7):683-9.

46. Liu C, Ma W, Su W, Zhang J. Prdm14 acts upstream of islet2 transcription to regulate axon growth of primary motoneurons in zebrafish. Development. 2012;139(24):4591-600.

47. Ross SE, McCord AE, Jung C, Atan D, Mok SI, Hemberg M, et al. Bhlhb5 and Prdm8 form a repressor complex involved in neuronal circuit assembly. Neuron. 2012;73(2):292-303.

48. Kajimura S, Seale P, Kubota K, Lunsford E, Frangioni JV, Gygi SP, et al. Initiation of myoblast to brown fat switch by a PRDM16-C/EBP-beta transcriptional complex. Nature. 2009;460(7259):1154-8. 
49. Cretney E, Xin A, Shi W, Minnich M, Masson F, Miasari M, et al. The transcription factors Blimp-1 and IRF4 jointly control the differentiation and function of effector regulatory T cells. Nat Immunol. 2011;12(4):304-11.

50. Carling T, Kim KC, Yang XH, Gu J, Zhang XK, Huang S. A histone methyltransferase is required for maximal response to female sex hormones. Mol Cell Biol. 2004;24(16):7032-42.

51. Patten I, Placzek M. The role of Sonic hedgehog in neural tube patterning. Cell Mol Life Sci. 2000;57(12):1695-708.

52. Wilson $L$, Maden $M$. The mechanisms of dorsoventral patterning in the vertebrate neural tube. Dev Biol. 2005;282(1):1-13.

53. Melton KR, lulianella A, Trainor PA. Gene expression and regulation of hindbrain and spinal cord development. Front Biosci. 2004;9:117-38.

54. Ericson J, Briscoe J, Rashbass P, van Heyningen V, Jessell TM. Graded sonic hedgehog signaling and the specification of cell fate in the ventral neural tube. Cold Spring Harb Symp Quant Biol. 1997;62:451-66.

55. Marti E, Bumcrot DA, Takada R, McMahon AP. Requirement of $19 \mathrm{~K}$ form of Sonic hedgehog for induction of distinct ventral cell types in CNS explants. Nature. 1995;375(6529):322-5.

56. Roelink H, Augsburger A, Heemskerk J, Korzh V, Norlin S, Ruiz i Altaba A, et al. Floor plate and motor neuron induction by vhh-1, a vertebrate homolog of hedgehog expressed by the notochord. Cell. 1994;76(4):761-75.

57. Ericson J, Muhr J, Jessell TM, Edlund T. Sonic hedgehog: a common signal for ventral patterning along the rostrocaudal axis of the neural tube. Int J Dev Biol. 1995;39(5):809-16.

58. Briscoe J, Ericson J. The specification of neuronal identity by graded Sonic Hedgehog signalling. Semin Cell Dev Biol. 1999;10(3):353-62.

59. Roelink H, Porter JA, Chiang C, Tanabe Y, Chang DT, Beachy PA, et al. Floor plate and motor neuron induction by different concentrations of the amino-terminal cleavage product of sonic hedgehog autoproteolysis. Cell. 1995:81(3):445-55.

60. Tanabe $Y$, Roelink H, Jessell TM. Induction of motor neurons by Sonic hedgehog is independent of floor plate differentiation. Curr Biol. 1995;5(6):651-8.

61. Ericson J, Morton S, Kawakami A, Roelink H, Jessell TM. Two critical periods of Sonic Hedgehog signaling required for the specification of motor neuron identity. Cell. 1996;87(4):661-73.

62. Ruiz i Altaba A, Nguyen V, Palma V. The emergent design of the neural tube: prepattern, SHH morphogen and GLI code. Curr Opin Genet Dev. 2003;13(5):513-21.

63. Chiang $C$, Litingtung $Y$, Lee $E$, Young $K E$, Corden $J$, Westphal $H$, et al. Cyclopia and defective axial patterning in mice lacking Sonic hedgehog gene function. Nature. 1996;383(6599):407-13.

64. Ericson J, Rashbass P, Schedl A, Brenner-Morton S, Kawakami A, van Heyningen $\mathrm{V}$, et al. Pax6 controls progenitor cell identity and neuronal fate in response to graded Shh signaling. Cell. 1997:90(1):169-80.

65. Qiu M, Shimamura K, Sussel L, Chen S, Rubenstein JL. Control of anteroposterior and dorsoventral domains of Nkx-6.1 gene expression relative to other Nkx genes during vertebrate CNS development. Mech Dev. 1998;72(1-2):77-88.

66. Briscoe J, Sussel L, Serup P, Hartigan-O'Connor D, Jessell TM, Rubenstein JL, et al. Homeobox gene Nkx2.2 and specification of neuronal identity by graded Sonic hedgehog signalling. Nature. 1999;398(6728):622-7.

67. Pierani A, Brenner-Morton S, Chiang C, Jessell TM. A sonic hedgehogindependent, retinoid-activated pathway of neurogenesis in the ventral spinal cord. Cell. 1999;97(7):903-15.

68. Briscoe J, Pierani A, Jessell TM, Ericson J. A homeodomain protein code specifies progenitor cell identity and neuronal fate in the ventral neural tube. Cell. 2000:101(4):435-45.

69. Novitch $\mathrm{BG}$, Chen $\mathrm{Al}$, Jessell TM. Coordinate regulation of motor neuron subtype identity and pan-neuronal properties by the bHLH repressor Olig2. Neuron. 2001;31(5):773-89.

70. Vallstedt A, Muhr J, Pattyn A, Pierani A, Mendelsohn M, Sander M, et al. Different levels of repressor activity assign redundant and specific roles to Nkx6 genes in motor neuron and interneuron specification. Neuron. 2001;31(5):743-55.

71. Pabst O, Herbrand $\mathrm{H}$, Takuma N, Arnold HH. NKX2 gene expression in neuroectoderm but not in mesendodermally derived structures depends on sonic hedgehog in mouse embryos. Dev Genes Evol. 2000;210(1):47-50.

72. Komai T, Iwanari H, Mochizuki Y, Hamakubo T, Shinkai Y. Expression of the mouse PR domain protein Prdm8 in the developing central nervous system. Gene Expr Patterns. 2009;9(7):503-14.
73. Zannino DA, Downes GB, Sagerström CG. prdm12b specifies the p1 progenitor domain and reveals a role for $\mathrm{V} 1$ interneurons in swim movements. Dev Biol. 2014;390(2):247-60.

74. Kinameri E, Inoue T, Aruga J, Imayoshi I, Kageyama R, Shimogori T, et al. Prdm proto-oncogene transcription factor family expression and interaction with the Notch-Hes pathway in mouse neurogenesis. PLoS One. 2008;3(12):e3859.

75. Lee KJ, Jessell TM. The specification of dorsal cell fates in the vertebrate central nervous system. Annu Rev Neurosci. 1999;22:261-94.

76. Chizhikov W, Millen KJ. Roof plate-dependent patterning of the vertebrate dorsal central nervous system. Dev Biol. 2005;277(2):287-95.

77. Timmer JR, Wang C, Niswander L. BMP signaling patterns the dorsal and intermediate neural tube via regulation of homeobox and helix-loop-helix transcription factors. Development. 2002;129(10):2459-72.

78. Chesnutt C, Burrus LW, Brown AM, Niswander L. Coordinate regulation of neural tube patterning and proliferation by TGFbeta and WNT activity. Dev Biol. 2004;274(2):334-47.

79. Wine-Lee L, Ahn KJ, Richardson RD, Mishina Y, Lyons KM, Crenshaw 3rd EB. Signaling through BMP type 1 receptors is required for development of interneuron cell types in the dorsal spinal cord. Development. 2004;131(21):5393-403

80. Hanotel J, Bessodes N, Thelie A, Hedderich M, Parain K, Driessche BV, et al. The Prdm13 histone methyltransferase encoding gene is a Ptf1a-Rbpj downstream target that suppresses glutamatergic and promotes GABAergic neuronal fate in the dorsal neural tube. Dev Biol. 2014;386(2):340-57

81. Matsukawa S, Miwata K, Asashima M, Michiue T. The requirement of histone modification by PRDM12 and Kdm4a for the development of pre-placodal ectoderm and neural crest in Xenopus. Dev Biol. 2015;399(1):164-76.

82. Lupo G, Harris WA, Lewis KE. Mechanisms of ventral patterning in the vertebrate nervous system. Nat Rev Neurosci. 2006;7(2):103-14.

83. McMahon JA, Takada S, Zimmerman LB, Fan CM, Harland RM, McMahon AP. Noggin-mediated antagonism of BMP signaling is required for growth and patterning of the neural tube and somite. Genes Dev. 1998;12(10):1438-52.

84. Liem Jr KF, Jessell TM, Briscoe J. Regulation of the neural patterning activity of sonic hedgehog by secreted BMP inhibitors expressed by notochord and somites. Development. 2000;127(22):4855-66.

85. Patten I, Placzek M. Opponent activities of Shh and BMP signaling during floor plate induction in vivo. Curr Biol. 2002;12(1):47-52.

86. Barth KA, Kishimoto Y, Rohr KB, Seydler C, Schulte-Merker S, Wilson SW. Bmp activity establishes a gradient of positional information throughout the entire neural plate. Development. 1999;126(22):4977-87.

87. Nguyen VH, Trout J, Connors SA, Andermann P, Weinberg E, Mullins MC Dorsal and intermediate neuronal cell types of the spinal cord are established by a BMP signaling pathway. Development. 2000;127(6):1209-20.

88. Bertrand N, Medevielle F, Pituello F. FGF signalling controls the timing of Pax6 activation in the neural tube. Development. 2000;127(22):4837-43.

89. Diez del Corral R, Breitkreuz DN, Storey KG. Onset of neuronal differentiation is regulated by paraxial mesoderm and requires attenuation of FGF signalling. Development. 2002;129(7):1681-91.

90. Novitch BG, Wichterle $H$, Jessell TM, Sockanathan S. A requirement for retinoic acid-mediated transcriptional activation in ventral neural patterning and motor neuron specification. Neuron. 2003;40(1):81-95.

91. Muroyama Y, Fujihara M, Ikeya M, Kondoh H, Takada S. Wnt signaling plays an essential role in neuronal specification of the dorsal spinal cord. Genes Dev. 2002;16(5):548-53.

92. Berggren K, McCaffery P, Drager U, Forehand CJ. Differential distribution of retinoic acid synthesis in the chicken embryo as determined by immunolocalization of the retinoic acid synthetic enzyme, RALDH-2. Dev Biol. 1999;210(2):288-304.

93. Schafer M, Kinzel D, Neuner C, Schartl M, Volff JN, Winkler C. Hedgehog and retinoid signalling confines $n k x 2.2 b$ expression to the lateral floor plate of the zebrafish trunk. Mech Dev. 2005;122(1):43-56.

94. Wilson L, Gale E, Chambers D, Maden M. Retinoic acid and the control of dorsoventral patterning in the avian spinal cord. Dev Biol. 2004;269(2):433-46.

95. Diez del Corral R, Olivera-Martinez I, Goriely A, Gale E, Maden M, Storey K. Opposing FGF and retinoid pathways control ventral neural pattern, neuronal differentiation, and segmentation during body axis extension. Neuron. 2003;40(1):65-79.

96. Molotkova N, Molotkov A, Sirbu IO, Duester G. Requirement of mesodermal retinoic acid generated by Raldh2 for posterior neural transformation. Mech Dev. 2005;122(2):145-55. 
97. Maden M. Retinoids and spinal cord development. J Neurobiol. 2006;66(7):726-38.

98. Gunesdogan U, Magnusdottir E, Surani MA. Primoridal germ cell specification: a context-dependent cellular differentiation event. Philos Trans R Soc Lond B Biol Sci. 2014;369(1657). doi: 10.1098/rstb.2013.0543

99. Sander M, Paydar S, Ericson J, Briscoe J, Berber E, German M, et al. Ventral neural patterning by Nkx homeobox genes: Nkx6.1 controls somatic motor neuron and ventral interneuron fates. Genes Dev. 2000;14(17):2134-9.

100. Muhr J, Andersson E, Persson M, Jessell TM, Ericson J. Groucho-mediated transcriptional repression establishes progenitor cell pattern and neuronal fate in the ventral neural tube. Cell. 2001;104(6):861-73.

101. Pierani A, Moran-Rivard L, Sunshine MJ, Littman DR, Goulding M, Jessell TM. Control of interneuron fate in the developing spinal cord by the progenitor homeodomain protein Dbx1. Neuron. 2001;29(2):367-84.

102. Zhou Q, Anderson DJ. The bHLH transcription factors OLIG2 and OLIG1 couple neuronal and glial subtype specification. Cell. 2002;109(1):61-73.

103. Filippi A, Tiso N, Deflorian G, Zecchin E, Bortolussi M, Argenton F. The basic helix-loop-helix olig3 establishes the neural plate boundary of the trunk and is necessary for development of the dorsal spinal cord. Proc Natl Acad Sci U S A. 2005;102(12):4377-82.

104. Muller T, Anlag K, Wildner H, Britsch S, Treier M, Birchmeier C. The bHLH factor Olig3 coordinates the specification of dorsal neurons in the spinal cord. Genes Dev. 2005;19(6):733-43.

105. Tiso N, Filippi A, Benato F, Negrisolo E, Modena N, Vaccari E, et al. Differential expression and regulation of olig genes in zebrafish. J Comp Neurol. 2009;515(3):378-96.

106. Hernandez-Lagunas L, Powell DR, Law J, Grant KA, Artinger KB. prdm1a and olig4 act downstream of Notch signaling to regulate cell fate at the neural plate border. Dev Biol. 2011;356(2):496-505.

107. Artinger KB, Chitnis AB, Mercola M, Driever W. Zebrafish narrowminded suggests a genetic link between formation of neural crest and primary sensory neurons. Development. 1999;126(18):3969-79.

108. Roy S, Ng T. Blimp-1 specifies neural crest and sensory neuron progenitors in the zebrafish embryo. Curr Biol. 2004;14(19):1772-7.

109. Hernandez-Lagunas L, Choi IF, Kaji T, Simpson P, Hershey C, Zhou Y, et al. Zebrafish narrowminded disrupts the transcription factor prdm1 and is required for neural crest and sensory neuron specification. Dev Biol. 2005;278(2):347-57.

110. Reid AG, Nacheva EP. A potential role for PRDM12 in the pathogenesis of chronic myeloid leukaemia with derivative chromosome 9 deletion. Leukemia. 2004;18(1):178-80.

111. Kolomietz E, Marrano P, Yee K, Thai B, Braude I, Kolomietz A, et al. Quantitative PCR identifies a minimal deleted region of $120 \mathrm{~kb}$ extending from the Philadelphia chromosome ABL translocation breakpoint in chronic myeloid leukemia with poor outcome. Leukemia. 2003;17(7):1313-23.

112. Benito-Gonzalez A, Alvarez FJ. Renshaw cells and la inhibitory interneurons are generated at different times from p1 progenitors and differentiate shortly after exiting the cell cycle. J Neurosci. 2012;32(4):1156-70.

113. Gosgnach S, Lanuza GM, Butt SJ, Saueressig H, Zhang Y, Velasquez T, et al. $V 1$ spinal neurons regulate the speed of vertebrate locomotor outputs. Nature. 2006;440(7081):215-9.

114. Alvarez FJ, Jonas PC, Sapir T, Hartley R, Berrocal MC, Geiman EJ, et al. Postnatal phenotype and localization of spinal cord $\mathrm{V} 1$ derived interneurons. J Comp Neurol. 2005;493(2):177-92.

115. Higashijima S, Masino MA, Mandel G, Fetcho JR. Engrailed-1 expression marks a primitive class of inhibitory spinal interneuron. J Neurosci. 2004;24(25):5827-39.

116. Li WC, Higashijima S, Parry DM, Roberts A, Soffe SR. Primitive roles for inhibitory interneurons in developing frog spinal cord. J Neurosci. 2004;24(25):5840-8.

117. Zhang J, Lanuza GM, Britz O, Wang Z, Siembab VC, Zhang Y, et al. V1 and $\mathrm{V} 2 \mathrm{~b}$ interneurons secure the alternating flexor-extensor motor activity mice require for limbed locomotion. Neuron. 2014;82(1):138-50.

118. Alvarez FJ, Benito-Gonzalez A, Siembab VC. Principles of interneuron development learned from Renshaw cells and the motoneuron recurrent inhibitory circuit. Ann N Y Acad Sci. 2013;1279:22-31.

119. Olesnicky E, Hernandez-Lagunas L, Artinger KB. prdm1a Regulates sox10 and islet 1 in the development of neural crest and Rohon-Beard sensory neurons. Genesis. 2010;48(11):656-66.

120. Sun XJ, Xu PF, Zhou T, Hu M, Fu CT, Zhang Y, et al. Genome-wide survey and developmental expression mapping of zebrafish SET domaincontaining genes. PLoS One. 2008;3(1):e1499.
121. Henke RM, Savage TK, Meredith DM, Glasgow SM, Hori K, Dumas J, et al. Neurog2 is a direct downstream target of the Ptf1a-Rbpj transcription complex in dorsal spinal cord. Development. 2009;136(17):2945-54.

122. Glasgow SM, Henke RM, Macdonald RJ, Wright CV, Johnson JE. Ptf1a determines GABAergic over glutamatergic neuronal cell fate in the spinal cord dorsal horn. Development. 2005;132(24):5461-9.

123. Bertrand N, Castro DS, Guillemot F. Proneural genes and the specification of neural cell types. Nat Rev Neurosci. 2002;3(7):517-30.

124. Batista MF, Lewis KE. Pax2/8 act redundantly to specify glycinergic and GABAergic fates of multiple spinal interneurons. Dev Biol. 2008;323(1):88-97.

125. Brohl D, Strehle M, Wende H, Hori K, Bormuth I, Nave KA, et al. A transcriptional network coordinately determines transmitter and peptidergic fate in the dorsal spinal cord. Dev Biol. 2008;322(2):381-93.

126. Cheng L, Arata A, Mizuguchi R, Qian Y, Karunaratne A, Gray PA, et al. Tl×3 and TIX1 are post-mitotic selector genes determining glutamatergic over GABAergic cell fates. Nat Neurosci. 2004;7(5):510-7.

127. Cheng L, Samad OA, Xu Y, Mizuguchi R, Luo P, Shirasawa S, et al. Lbx1 and Tlx3 are opposing switches in determining GABAergic versus glutamatergic transmitter phenotypes. Nat Neurosci. 2005;8(11):1510-5.

128. Helms AW, Battiste J, Henke RM, Nakada Y, Simplicio N, Guillemot F, et al. Sequential roles for Mash1 and Ngn2 in the generation of dorsal spinal cord interneurons. Development. 2005;132(12):2709-19.

129. Mizuguchi R, Kriks S, Cordes R, Gossler A, Ma Q, Goulding M. Ascl1 and Gsh1/2 control inhibitory and excitatory cell fate in spinal sensory interneurons. Nat Neurosci. 2006;9(6):770-8.

130. Wildner H, Muller T, Cho SH, Brohl D, Cepko CL, Guillemot F, et al. dILA neurons in the dorsal spinal cord are the product of terminal and nonterminal asymmetric progenitor cell divisions, and require Mash1 for their development. Development. 2006;133(11):2105-13.

131. Hori K, Cholewa-Waclaw J, Nakada Y, Glasgow SM, Masui T, Henke RM, et al. A nonclassical bHLH Rbpj transcription factor complex is required for specification of GABAergic neurons independent of Notch signaling. Genes Dev. 2008;22(2):166-78.

132. Beres TM, Masui T, Swift GH, Shi L, Henke RM, MacDonald RJ. PTF1 is an organ-specific and Notch-independent basic helix-loop-helix complex containing the mammalian Suppressor of Hairless (RBP-J) or its paralogue RBP-L. Mol Cell Biol. 2006;26(1):117-30

133. Masui T, Swift GH, Hale MA, Meredith DM, Johnson JE, Macdonald RJ. Transcriptional autoregulation controls pancreatic Ptf1a expression during development and adulthood. Mol Cell Biol. 2008;28(17):5458-68.

134. Storm R, Cholewa-Waclaw J, Reuter K, Brohl D, Sieber M, Treier M, et al. The bHLH transcription factor Olig3 marks the dorsal neuroepithelium of the hindbrain and is essential for the development of brainstem nuclei. Development. 2009;136(2):295-305.

135. Liu Z, Li H, Hu X, Yu L, Liu H, Han R, et al. Control of precerebellar neuron development by Olig3 bHLH transcription factor. J Neurosci. 2008;28(40):10124-33.

136. Bramblett DE, Copeland NG, Jenkins NA, and Tsai MJ, BHLHB4 is a bHLH transcriptional regulator in pancreas and brain that marks the dimesencephalic boundary. Genomics, 2002. 79(3): p. 402-12.

137. Joshi PS, Molyneaux BJ, Feng L, Xie X, Macklis JD, and Gan L, Bhlhb5 regulates the postmitotic acquisition of area identities in layers $\|-V$ of the developing neocortex. Neuron, 2008. 60(2): p. 258-72.

138. Ross SE, Mardinly AR, McCord AE, Zurawski J, Cohen S, Jung C, Hu L, Mok SI, Shah A, Savner EM, Tolias C, Corfas R, Chen S, Inquimbert P, Xu Y, Mclnnes RR, Rice FL, Corfas G, Ma Q, Woolf CJ, and Greenberg ME, Loss of inhibitory interneurons in the dorsal spinal cord and elevated itch in Bhlhb5 mutant mice. Neuron, 2010. 65(6): p. 886-98.

139. Peyton M, Stellrecht CM, Naya FJ, Huang HP, Samora PJ, and Tsai MJ, BETA3, a novel helix-loophelix protein, can act as a negative regulator of BETA2 and MyoD-responsive genes. Mol Cell Biol, 1996. 16(2): p. 626-33.

140. Xu ZP, Dutra A, Stellrecht CM, Wu C, Piatigorsky J, and Saunders GF, Functional and structural characterization of the human gene BHLHB5, encoding a basic helix-loop-helix transcription factor. Genomics, 2002. 80(3): p. 311-8.

141. Skaggs K, Martin DM, Novitch BG. Regulation of spinal interneuron development by the Olig-related protein Bhlhb5 and Notch signaling. Development. 2011;138(15):3199-211.

142. Liu B, Liu Z, Chen T, Li H, Qiang B, Yuan J, et al. Selective expression of Bhlhb5 in subsets of early-born interneurons and late-born association neurons in the spinal cord. Dev Dyn. 2007;236(3):829-35. 
143. Powell LM, Jarman AP. Context dependence of proneural bHLH proteins. Curr Opin Genet Dev. 2008;18(5):411-7.

144. Chang DH, Cattoretti G, Calame KL. The dynamic expression pattern of $B$ lymphocyte induced maturation protein-1 (Blimp-1) during mouse embryonic development. Mech Dev. 2002;117(1-2):305-9.

145. Robertson EJ, Charatsi I, Joyner CJ, Koonce CH, Morgan M, Islam A, et al. Blimp1 regulates development of the posterior forelimb, caudal pharyngeal arches, heart and sensory vibrissae in mice. Development. 2007:134(24):4335-45.

146. Wilm TP, Solnica-Krezel L. Essential roles of a zebrafish prdm1/blimp1 homolog in embryo patterning and organogenesis. Development 2005;132(2):393-404

147. Brzezinski JA, Lamba DA, Reh TA. Blimp1 controls photoreceptor versus bipolar cell fate choice during retinal development. Development. 2010;137(4):619-29.

148. Hoyt PR, Bartholomew C, Davis AJ, Yutzey K, Gamer LW, Potter SS, et al. The Evi1 proto-oncogene is required at midgestation for neural, heart, and paraxial mesenchyme development. Mech Dev. 1997;65(1-2):55-70.

149. Chittka A, Nitarska J, Grazini U, Richardson WD. Transcription factor positive regulatory domain 4 (PRDM4) recruits protein arginine methyltransferase 5 (PRMT5) to mediate histone arginine methylation and control neural stem cell proliferation and differentiation. J Biol Chem. 2012;287(51):42995-3006.

150. Chittka A. Differential regulation of SC1/PRDM4 and PRMT5 mediated protein arginine methylation by the nerve growth factor and the epidermal growth factor in PC12 cells. Neurosci Lett. 2013;550:87-92.

151. Yang XH, Huang S. PFM1 (PRDM4), a new member of the PR-domain family, maps to a tumor suppressor locus on human chromosome 12q23-q24.1. Genomics. 1999;61(3):319-25.

152. Ding HL, Clouthier DE, Artinger KB. Redundant roles of PRDM family members in zebrafish craniofacial development. Dev Dyn. 2013;242(1):67-79.

153. Meani N, Pezzimenti F, Deflorian G, Mione M, Alcalay M. The tumor suppressor PRDM5 regulates Wnt signaling at early stages of zebrafish development. PLoS One. 2009;4(1):e4273.

154. Wu Y, Ferguson 3rd JE, Wang $H$, Kelley $R$, Ren $R$, McDonough $H$, et al. PRDM6 is enriched in vascular precursors during development and inhibits endothelial cell proliferation, survival, and differentiation. J Mol Cell Cardiol. 2008;44(1):47-58

155. Inoue M, Kuroda T, Honda A, Komabayashi-Suzuki M, Komai T, Shinkai Y, et al. Prdm8 Regulates the Morphological Transition at Multipolar Phase during Neocortical Development. PLoS One. 2014;9(1):e86356.

156. Park JA, Kim KC. Expression patterns of PRDM10 during mouse embryonic development. BMB Rep. 2010;43(1):29-33.

157. Siegel DA, Huang MK, Becker SF. Ectopic dendrite initiation: CNS pathogenesis as a model of CNS development. Int J Dev Neurosci. 2002:20(3-5):373-89.

158. Chen YC, Auer-Grumbach M, Matsukawa S, Zitzelsberger M, Themistocleous AC, Strom TM, et al. Transcriptional regulator PRDM12 is essential for human pain perception. Nat Genet. 2015;47(7):803-8.

159. Nagy V, Cole T, Van Campenhout C, Khoung TM, Leung C, Vermeiren $S$, et al The evolutionarily conserved transcription factor PRDM12 controls sensory neuron development and pain perception. Cell Cycle. 2015;14(12):1799-808.

160. Nishikata I, Sasaki H, Iga M, Tateno Y, Imayoshi S, Asou N, et al. A novel EVI1 gene family, MEL1, lacking a PR domain (MEL1S) is expressed mainly in $\mathrm{t}(1 ; 3)(p 36 ; q 21)$-positive AML and blocks G-CSF-induced myeloid differentiation. Blood. 2003;102(9):3323-32

\section{Submit your next manuscript to BioMed Central and take full advantage of:}

- Convenient online submission

- Thorough peer review

- No space constraints or color figure charges

- Immediate publication on acceptance

- Inclusion in PubMed, CAS, Scopus and Google Scholar

- Research which is freely available for redistribution

Submit your manuscript at www.biomedcentral.com/submit 